\title{
IUGS PUBLICATIONS
}

All figures given in dollars, $\$$ are in U.S. funds

\section{REVIEWS:}

Almeida, F.F.M. de, Leonardos Jr., O.H., Valença, J. REVIEW ON GRANITIC ROCKS OF NORTHEAST SOUTH AMERICA. Prepared for the IUGS/UNESCO Symposium in Recife, Brazil, October 1967, 41p. \$9.00.

Didier, J. LES ENCLAVES DES GRANITES DANS LA LITTERATURE GEOLOGIQUE. B.R.G.M., Paris, (1964), 18p. \$0.50.

Dylik, J. and Maarleveld, G.C. FROST CRACKS, FROST FISSURES AND RELATED POLYGONS: A SUMMARY OF THE LITERATURE OF THE PAST DECADE. E. van Aelst, Maastricht, (1967), 15p. \$0.50.

Evans, I.S. SALT CRYSTALLIZATION AND ROCK WEATHERING: A REVIEW. Reprint from Revue de Geomorphologie Dynamique, No. 4, (1970), p. 153-177, $\$ 2.00$.

Maarleveld, G.C. FROST MOUNDS: A SUMMARY OF THE LITERATURE OF THE PAST DECADE. E. van Aelst, Maastricht, (1965), 16p. \$0.50.

REVIEWS PREPARED FOR THE FIRST SYMPOSIUM ON GONDWANA STRATIGRAPHY, MAR DEL PLATA, ARGENTINA, SEPTEMBER 1967. (1970), 304p. \$10.00.

\section{Order From:}

EPISODES Secretariat

Room 177

601 Booth Street

Ottawa, Ontario

Canada K1A $0 E 8$

Tel: $613-995-4927$

Telex: 0533117 EMAR-OTT

\section{IUGS SERIES A AND B}

Proceedings of symposia and of IUGS bodies are published in these Series. IUGS sets the specifications for the format of Series A $(240 \times 162 \mathrm{~mm}$ "congress size") and Series $B$ (297 $\times 210 \mathrm{~mm}$, A 4 size) and assigns the serial numbers. The volumes however, are not published by IUGS itself, but by different publishing houses. Unfortunately, subscription to the complete series is not possible. The publications are available from the publishers or addresses listed below.

Series A, Number 1:

Westermann, G.E.G. (ed.) SEXUAL DIMORPHISM IN FOSSIL METAZOA AND TAXONOMIC IMPLICATIONS. E. Schweizerbart'sche Verlagsbuchhandlung, Stuttgart, (1969), 251p. stiff cover \$19.80, DM 46.00. Symposium organized by the International Palaeontological Union, Committee on Evolution, Prague, 1968.

Series A, Number 2:

Pouba, Z. and Stemprok, M. (eds.) PROBLEMS OF HYDROTHERMAL ORE DEPOSITION. E. Schweizerbart'sche Verlagsbuchhandlung, Stuttgart, (1970), 396p. cloth bound DM 74.00. The origin, evolution and control of oreforming fluids. Symposium organized by the International Association on the Genesis of Ore Deposits, St. Andrews, Scotland, 1967.
Series A, Number 3:

Amstutz, G.C. and Bernard, A.J. (eds.) ORES IN SEDIMENTS. 2nd edition. Springer-Verlag, Berlin, Heidelberg and New York, (1976), 350p. \$25.60, DM 58.00. VIII International Sedimentological Congress, Heidelberg, August 31-September 3,1971.

Series A, Number 4:

Amstutz, G.C. (ed.) SPILITES AND SPILITIC ROCKS. Springer-Verlag, Berlin, Heidelberg and New York, (1974), 482 p. cloth $\$ 27.10$, DM 66.00

Series A, Number 5:

Martinsson, A. (ed.) THE SILURIAN-DEVONIAN BOUNDARY. E. Schweizerbart'sche Verlagsbuchhandlung, Stuttgart, (1977), 349p. stiff cover \$42.20, DM 98.00. Final report of the Committee on the Silurian-Devonian Boundary within IUGS Commission on Stratigraphy and a state of the art report for Project Ecostratigraphy.

\section{Series B, Number 1:}

Adie, R.J. (ed.) ANTARCTIC GEOLOGY AND GEOPHYSICS. Universitetsforlaget, Oslo, (1972), 876p. \$78.00, N.Kr. 390.00. Order addresses: Universitetsforlaget, P.O. Box 307, Blindern Oslo 3, Norway, or Box 142, Boston, Mass., 02113, U.S.A., or Global Book Resources, 37. Queen Street, Henley on Thames, Oxon RG9 1AJ, U.K. Proceedings of the 2nd Symposium on Antarctic Geology and Solid Earth Geophysics, held in Oslo, August 6-15, 1970.

Series B, Number 2:

Collins, B.W. and Fraser, R. (eds.) RECENT CRUSTAL MOVEMENTS AND ASSOCIATED SEISMICITY. Royal Society of New Zealand, Bulletin 9, (1971), 247p. NZ $\$ 8.00$. Order address: The General Secretary, The Royal Society of New Zealand, P.O. Box 12249, Wellington, New Zealand. Selected papers of the International Symposium on Recent Crustal Movements and Associated Seismicity, held in Wellington in February 1970.

Series B, Number 3:

Burger, A. and Dubertret, L. (eds.) HYDROGEOLOGY OF KARSTIC TERRAINS/HYDROGEOLOGIE DES TERRAINS KARSTIQUES. Published by the International Association of Hydrogeologists, Paris, (1975), 190p. \$20.00. Order address: Dr. E. Groba, Treasurer of IAH, Landesamt fur Bodenforschung, Postfach 510153, $\$ 000$ Hannover 51, Federal Republic of Germany.

Hedberg, H.D. (ed.) INTERNATIONAL STRATIGRAPHIC GUIDE; A Guide to Stratigraphic Classification, Terminology, and Procedure. IUGS, International Subcommission on Stratigraphic Classification; John Wiley \& Sons, Inc., 605 Third Avenue, New York, N.Y. 10016, U.S.A., (1976), 200p. 